\title{
Hubungan Antara Penilaian Anak Terhadap Cerita Film Anak di Televisi dengan Kemampuan Empati Pada Anak Usia Sekolah Dasar
}

\author{
Ratna Sesotya Wedadjati \\ Sekolah Tinggi Pemerintahan Masyarakat Desa "APMD” \\ Ratnasesotya@yahoo.com
}

This research aims at examining a correlation between judgment of children film on television and empathy ability. Samples of this research are ninety three $(N=93)$ children of elementary school, age between nine to twelve years old in SDN Ngetal Sleman. Instruments used are judgment of children film on television and empathy ability scales. Data are analyzed using the correlation analysis of product moment program based on the SPSS for Windows 13 release. Statistical test reveals that there is significant correlation between the level of judgment of children film on television and empathy ability ( $r=0.382$; $p=0.000$ or $p<0.01$ ).

Keywords: judgment, children film, television, empathy ability.

\section{PENDAHULUAN}

$\mathrm{P}$ ada era kemajuan ilmu pengetahuan dan teknologi masa sekarang ini modernisasi sebagai tahapan perkembangan masyarakat seakan-akan telah menampakkan wujudnya yang paling nyata. Pesatnya kemajuan ilmu pengetahuan dan teknologi telah membawa umat manusia ke dalam kemudahan dan kepraktisan hidup sebelumnya tidak pernah terbayangkan, sebagai contoh dengan adanya telepon selluler atau hand phone yang sangat kecil akan tetapi mampu melakukan berbagai macam kegiatan bisnis dan kemudahan memperoleh ilmu pengetahuan dan informasi, kalangan yang memilikinya tidak hanya orang dewasa tetapi anak-anak yang masih duduk dibangku sekolah dasar bahkan sampai usia prasekolah juga sudah memiliki benda tersebut yang digunakan untuk mempermudah komunikasi (Seluler, 2003).

Pendidikan dalam keluarga sejak dini sangat penting bagi anak-anak dan harus dibiasakan untuk belajar bagaimana memikirkan kepentingan orang lain. Sebagaimana penelitian komparatif yang pernah dilakukan Hadipranata (1994) mengenai kebersihan, kejujuran, kerjasama, dan kepemimpinan antara siswa taman kanakkanak Jepang dengan Indonesia, ternyata menunjukkan bahwa anak-anak Jepang lebih unggul daripada anak-anak Indonesia. 
UNISIA, Vol. XXXII No. 72 Desember 2009

Bahwa anak-anak Jepang sudah mampu melakukan empati, ketika mereka ditanya alasan tentang sikap jujur mereka pada penjual makanan yang berdagang dengan menggunakan sistem swalayan, jawabnya adalah "kalau kami tidak membayar, maka paman penjual akan rugi, dan kalau paman penjual rugi maka mereka tidak dapat lagi berdagang". Hasil penelitian tersebut menunjukkan bahwa di Indonesia telah terjadi penurunan kemampuan berempati sejak anak masih berusia dini (Dayakisni, 1996).

Fenomena menipisnya kemampuan berempati di kalangan anak-anak masa sekarang dipengaruhi oleh perkembangan IPTEK serta pembangunan yang memang telah menampakkan banyak hasil, akan tetapi juga belum berhasil mengatasi berbagai dampaknya yang eksesif, misalnya dampak transformasi dari masyarakat rural agraris ke masyarakat urban industrial (Jatman, 2003).

Pada saat ini perilaku anak-anak bermain banyak berubah, anak-anak sekarang cenderung menyukai permainan individual seperti : main PS, game-game di internet, main game di hand phone dan lainlain. Hal ini jelas saja menghambat kemampuan berempati dan juga beriteraksi dengan orang lain. Permasalahan ini begitu penting karena masa kanak-kanak memberikan kontribusi yang begitu menentukan bagi terbentuknya kepribadian seseorang, dasar awal yang dibangun pada masa kanak-kanak biasanya cenderung menetap dan mempengaruhi bagaimana anak bersikap dan berperilaku pada masamasa selanjutnya demikian juga dalam kaitanya dengan kemampuan berempati pada anak-anak. Stimulus yang memungkinkan tumbuh kemampuan empati selama masa kanak-kanak akan mempengaruhi perkembangan empati pada masa-masa selanjutnya, karena anak merupakan modal pembangunan bangsa, dan sebagai modal maka anak harus mendapat porsi yang setara dan sejajar dengan kelompok masyarakat lainnya dalam semua aspek kehidupan (Tuhehay, 2003)

Salah satu cara yang dapat dilakukan untuk membantu mengembangkan kemampuan empati pada anak adalah dengan menggunakan media televisi, karena anak pada masa sekarang begitu dekat dengan media dan mereka akan lebih mudah menyerap pesan-pesan yang disampaikan secara audio dan visual. Segall (1988) (dalam Crick, 1997) menyatakan, bahwa setiap manusia belajar peran kebiasaankebiasaan yang bersifat kultural dari lingkungan sekitarnya yang tidak hanya terbatas pada lingkungan keluarga akan tetapi juga meliputi seluruh kelengkapan instrumen dan sarana benda yang ada dalam keluarga, misalnya : televisi, radio, dan komputer. Televisi merupakan media audio visual yang menampilkan gambar dan suara tentu paling menarik bagi anak-anak, lagi pula kemampuan televisi sangat luar biasa karena dapat mempengaruhi cara berpikir serta perilaku anak-anak.

\section{Kajian Pustaka}

Hasil suvey mengenai kehidupan anak yang berjudul Kid's World-The Future Market pada Mei hingga Juni 2001, menunjukkan bagaiman intensnya anak dengan dunia televisi. Survey dilaksanakan pada anak berusia 7-14 tahun dan ibu dari anak berusia 0-14 tahun dari semua kelompok sosial ekonomi di enam kota, yaitu Jakarta, Bandung, Semarang, Surabaya, Medan dan Makasar. Hasil yang diperoleh adalah sebagaian anak terekspos ke media televisi sejak bayi (25\%). Begitu usia menginjak lebih dari satu tahun, hampir semua terbiasa menonton televisi (92\%). Ketika masuk usia 
Hubungan Antara Penilaian Anak Terhadap Cerita Film...; Ratna Sesotya Wedadjati

TK (4-6 tahun) hingga usia SMP (12-14 tahun), semua sudah menjadi penonton setia televisi (Puspito, 2002).

Survey yang dilakukan di Amerika, menunjukkan bahwa seorang anak yang telah tamat SMU (sekolah menengah umum), mereka telah menghabiskan waktu sekitar 15.000 jam untuk menonton televisi dan setiap anak rata-rata menyaksikan televisi selama 3 jam sehari maka dalam setahun mereka sudah menghabiskan waktu untuk menonton televisi sekitar 1095 jam dan menonton televisi ini sudah di mulai sejak usia 4 atau 5 taun. Jumlah waktu ini lebih banyak di pakai untuk menonton televisi daripada yang dipakai untuk kegiatan lainnya selain tidur. Selama 15.000 jam, mereka telah diperlihatkan dengan 350.000 iklan dan telah menyaksikan 18.000 pembunuhan (Lewis, 1993).

Televisi memercikkan rasa ingin tahu pada anak-anak dan membuka mata terhadap dunia yang jauh, lewat pesonanya anak-anak dapat terbawa ke dunia hayal, entah itu angkasa luar ataupun dasar samudra. Televisi merupakan salah satu produk teknologi yang dapat berdampak positif dan negatif. Dampak positif televisi antara lain adalah bahwa televisi dapat membantu orang tua dalam membantu anak menemukan bakatnya, televisi dapat mengumpulkan dan mendekatkan keluarga, televisi dapat merangsang percakapan para anggota keluarga, televisi dapat memberikan hiburan yang sehat, acara-acara pendidikan dapat menjadi bagian dari lingkungan belajar yang dapat membantu orang tua serta memudahkan orang untuk memperoleh informasi global dari seluruh dunia, dan menambah ilmu pengetahuan.

Kota Yogyakarta dengan cara yang unik mulai mensiasati dampak gangguan siaran televisi terhadap pendidikan anakanak. Caranya dengan menyapih sejenak paparan TV, melalui program Jam Belajar Masyarakat (JBM) (Intisari, 1999), walaupun program tersebut tidak terlalu berarti akan tetapi ada manfaatnya dalam mewujudkan lingkungan yang mendukung proses belajar, program ini secara langsung mengajak orangtua ikut peduli terhadap pendidikan anak-anak, sehingga orangtua juga harus pandai-pandai memilihkan dan menyaring acara-acara televisi yang dihadirkan sebagai media massa dan berusaha mengajarkan pada anak untuk mematikan televisi jika acara atau program yang dipilihkan sudah berakhir, sedangkan dampak negatifnya begitu meresahkan bagi masyarakat, orangtua, para pendidik, ulama dan orangorang yang memperhatikan masalah anak.

Menurut Hurlock (1991) menonton televisi dikalangan anak-anak merupakan kegiatan yang lebih populer daripada mendengarkan radio, meskipun anak senang mendengarkan musik atau beritaberita olah raga yang tidak disiarkan di televisi. Menonton televisi merupakan salah satu hiburan yang disukai oleh sebagian anak-anak. Mereka senang pertunjukan kartun dan acara-acara lain yang diperuntukkan bagi tingkat usianya di samping acara-acara untuk orang dewasa. Leifer, dkk (Hurlock, 1991), menyatakan bahwa televisi bukan hanya merupakan hiburan bagi anakanak-tetapi juga sarana sosialisasi yang penting.

Penelitian yang dilakukan oleh Lorch dkk (1987), menghasilkan data bahwa ada perbedaan tingkat usia anak dalam mengingat informasi penting yang disampaikan melalui film di televisi, pada anak yang usianya lebih kecil (6 tahun ke bawah) masih sulit membedakan dengan informasi yang ada dikehidupan nyata sedang usia yang lebih besar (6 tahun ke atas) akan lebih mudah membedakan antara cerita dalam film dan kenyataan dilingkungannya. 
UNISIA, Vol. XXXII No. 72 Desember 2009

Menurut Dhamayanti (2002), di Indonesia acara film televisi untuk anak yang di puji-puji oleh para orangtua adalah film Teletubbies, dimana dalam film tersebut banyak ditampilkan hal-hal yang positif antara lain; informasi dan pengetahuan, ketrampilan dasar dalam berhubungan dengan orang, maupun perilaku-perilaku sosial yang bersifat prososial misalnya; menolong, bekerja sama atau berbagi dengan orang lain. Film ini cocok diberikan atau ditonton oleh anak usia prasekolah karena film ini ditampilkan sangat sederhana dan mudah dicerna karena adegannya di ulang-ulang, sehingga anak akan mudah meniru informasi--informasi kebaikan yang diberikan oleh film tersebut dan dapat membantu anak untuk belajar, misalnya; setiap bertemu orang mengucapkan "hallo apa kabar" atau "selamat pagi" dan perilaku prososial serta menjalin persahabatan.

Vandell (2000), menyatakan bahwa di Amerika rata-rata anak yang berusia 2 - 5 tahun dalam setiap minggu menonton televisi sebanyak 30 sampai 54 jam berarti rata-rata anak menonton televisi 5 - 10 jam perharinya. Melihat kenyataan ini, perlu adanya perhatian dan bimbingan orangtua kepada anak-anaknya agar memilih acara yang sesuai untuk usianya dan mendampingi anak agar dapat memberi pengertian kepada anak akan makna tayangan yang sedang di tonton, karena kebanyakan kegiatan menonton televisi cenderung tidak terencana dan bersifat tidak sadar dimana setiap kali seorang anak mempunyai waktu luang dengan seenaknya akan langsung merebahkan diri di sofa atau karpet kemudian mengambil alat pengendali jarak jauh (remote control) dan tidak memilih-milih lagi program yang akan di saksikan.

Menurut Milton, direktur riset CTW (Children's Television work-shop) New York, pengembangan program-program televisi pendidikan semisal Sesame Street, One TV, The electric company merupakan acara pendidikan yang memanfaatkan media televisi di New York yang sangat membantu orangtua dalam memberikan pendidikan untuk anak-anaknya secara praktis dimana orang tua akan mendampingi dan menerangkan kepada anak tentang apa yang, dilihat, di Indonesia acara tersebut juga telah ditayangkan misalnya Sesame Street, National Geographic, serta Discovery Channel yang berisi tentang pendidikan dan pengetahuan dunia, akan tetapi masih kurang dimanfaatkan oleh orangtua sebagai sarana pendidikan yang mudah dan praktis karena orangtua banyak yang tidak mau mendampingi anaknya dalam menonton acara kesibukan kerja (Intisari, 1999).

Penelitian Ladd dkk ( 1983), tentang perilaku menolong pada anak yang dilihat dari pengaruh situasi dan kepribadian, menunjukkan bahwa perilaku menolong muncul ketika ada informasi dan contoh dari orang lain sebelumnya sehingga anak akan berusaha berbuat baik karena sesuatu yang dilihat kemudian ditirukan.

Penelitian yang dilakukan Hafni (2002), mengenai pengaruh diskusi tayangan film prososial terhadap perilaku agresif anak menunjukkan bahwa ada pengaruh diskusi tayangan film prososial terhadap perilaku agresif anak, anak yang mendapat perlakuan berupa diskusi tayangan film prososial agresinya lebih rendah dihandingkan anak yang tidak mendapat perlakuan (kelompok kontrol), sedangkan hipotesis lain yang berhunyi anak yang mendapat perlakuan menonton tayangan film prososial perilaku agresifnya rendah di banding anak yang tidak mendapatkan perlakuan di tolak, karena tidak ada pengaruh. Memperhatikan hasil penelitian di atas bahwa, setelah diberi perlakuan diskusi tayangan film prososial, perilaku agresif anak menjadi turun berarti 
Hubungan Antara Penilaian Anak Terhadap Cerita Film...; Ratna Sesotya Wedadjati

dapat dijelaskan, bahwa pada saat berlangsungnya diskusi, dalam diri anak terjadi proses penambahan pengetahuan tentang nilai-nilai atau norma-norrna yang dapat dijadikan kontrol dalam dirinya.

\section{Metode Penelitian}

Variabel bebas dalam penelitian ini adalah penilaian anak terhadap cerita film anak di televisi dan variabel tergantung adalah kemampuan empati anak. Metode yang digunakan untuk mengumpulkan data adalah dengan skala penilaian anak terhadap cerita film anak di televisi dan skala kemampuan empati.

Skala penilaian anak terhadap cerita film disusun sendiri oleh peneliti berdasarkan jadwal film cerita yang ditayangkan ditelevisi Indonesia, berdasarkan dua aspek yaitu :gaya pencerita maksudnya, cara pengarang menyampaikan ide dan gagasan dengan menggunakan bahasa yang indah serta mampu menuansakan makna dan suasana yang dapat mengembangkan daya intelektual dan membangkitkan emosi penontonnya atau disebut aspek kemenarikan cerita, dan karakter tokoh yang merupakan watak, sifat tau perangai tokoh atau pelaku yang hadir dalam sebuah cerita atau disebut aspek karakter tokoh dalam cerita.

Untuk mengungkap kedua aspek tersebut disusun sebanyak 28 butir pada setiap pernyataan butir terdapat empat pilihan jawaban yaitu : Sangat Setuju (SS), Setuju (S), Tidak Setuju (TS), Sangat Tidak Setuju (STS). Untuk melihat tingkat konsistensi jawaban, pertanyaan disusun dalam dua bentuk yaitu favorabel (+) dan unfavorabel (-). Arah pemberian skor tergantung pada favorabel atau tidaknya suatu butir. Pada pernyataan favorabel diberi bobot 4,3,2,1 dan untuk pernyataan unfavorabel diberi bobot 1,2,3,4. Hasil uji coba menunjukkan dua item dinyatakan tidak layak, sehingga yang dipergunakan dalam penelitian ini 26 item dengan tingkat reliabilitas (nilai alpha) sebesar 0.9111 .

Skala kemampuan empati disusun sendiri oleh peneliti berdasarkan aspek yang bersifat multidimensional dari Davis (1983). Penyusunan butir-butir pernyataan pada skala kemampuan empati didasarkan pada empat aspek yaitu : fantasy, empathic concern, perspective taking dan personal distress.

Untuk mengungkap keempat aspek tersebut disusun sebanyak 40 butir pada setiap pernyataan butir terdapat empat pilihan jawaban yaitu : Sering Sekali (SS), Sering (SG), Jarang Sekali (JS), Tidak Pernah (TP). Untuk melihat tingkat konsistensi jawaban, pertanyaan disusun dalam dua bentuk yaitu favorabel (+) dan unfavorabel (-). Arah pemberian skor tergantung pada favorabel atau tidaknya suatu butir. Pada pernyataan favorabel diberi bobot 4,3,2,1 dan untuk pernyataan unfavorabel diberi bobot 1,2,3,4. Hasil uji coba menunjukkan 9 item dinyatakan tidak layak, sehingga yang dipergunakan dalam penelitian ini 29 item dengan tingkat reliabilitas (nilai alpha) sebesar 0.9144.

Subjek penelitian sebanyak 93 siswa siswi sekolah dasar Ngetal Sleman. Data hasil penelitian ini akan dianalisis menggunakan analisis product moment dari Pearson dengan bantuan program statistik SPSS versi 13.

\section{Hasil Penelitian dan Pembahasan}

\section{Deskripsi Subjek Penelitian}

Pemilihan subjek dalam penelitian adalah dengan cara kluster (cluster random sampling), yaitu dengan melakukan ran- 
UNISIA, Vol. XXXII No. 72 Desember 2009

domisasi terhadap kelompok, bukan terhadap subjek secara individual. Karakteristik subjek penelitian adalah siswa siswi SDN Ngetal Sleman, berusia antara 9-12 tahun dan memiliki pesawat televisi dirumahnya. Jumlah subjek dalam penelitian ini sebanyak 93 siswa, laki-laki $=48$ dan perempuan $=45$.

Skor mentah (raw-score) yang dihasilkan suatu skala merupakan penjumlahan dari aitem-aitem dalam skala itu, skor skala harus dibuatkan pembanding agar dapat diinterpretasikan (Azwar, 1998). Kriteria kategori ditetapkan oleh peneliti guna mendapatkan informasi tentang keadaan kelompok subjek pada variabel yang diteliti. Dalam penelitian ini akan dibuat kategorisasi masing-masing variabel dengan menggolongkan menjadi tiga kategori yaitu tinggi, sedang dan rendah.

Cara kategorisasi subyek secara normatif menggunakan model distribusi normal berdasarkan asumsi bahwa skor dalam kelompoknya merupakan estimasi terhadap skor subjek dalam populasinya dan skor tersebut terdistribusi normal (Azwar, 1999).

Kategorisasi subjek pada variabel empati akan dikelompokkan dalam tiga kategori yaitu tinggi, sedang dan rendah. Kategorisasi yang digunakan adalah model distribusi normal dengan batasan kategori skala berdasarkan mean skor skala (M), deviasi standart dengan (s), skor minimum (Xmin) dan skor maksimum (Xmaks) (Azwar, 1999).

Kategorisasi dibuat berdasarkan tiga kategori dengan penggolongan seperti pada tabel 2.

\section{Hasil Uji Asumsi}

Uji hipotesis dilakukan setelah uji prasarat atau uji asumsi yang meliputi uji normalitas dan uji linieritas hubungan. Adapun hasil uji asumsi yaitu :

1). Uji Normalitas Sebaran.

Uji normalitas sebaran dilakukan dengan menggunakan one-sample Kolmo-

Tabel 1. Deskripsi data penelitian

\begin{tabular}{|l|l|l|c|c|c|c|c|c|}
\hline \multirow{3}{*}{ Variabel } & \multicolumn{4}{|c|}{$\begin{array}{c}\text { Skor yang } \\
\text { dimungkinkan (hipotetik) }\end{array}$} & \multicolumn{4}{c|}{$\begin{array}{c}\text { Skor yang } \\
\text { diperoleh (empirik) }\end{array}$} \\
\cline { 2 - 10 } & Xmin & Xmak & Mean & SD & Xmin & Xmak & Mean & SD \\
\hline $\begin{array}{l}\text { Penilaian } \\
\text { anak }\end{array}$ & 26 & 104 & 65 & 13 & 70 & 104 & 86.8857 & 7.10285 \\
\hline Empati & 29 & 116 & 87 & 6,33 & 70 & 105 & 87.5914 & 8.5988 \\
\hline
\end{tabular}

Tabel 2. Kategori subjek pada skala penilaian anak

\begin{tabular}{|l|c|c|c|}
\hline \multicolumn{1}{|c|}{ Kategori } & Rentang skor & Jumlah & Frekuensi (\%) \\
\hline Tinggi & $91-104$ & 20 & 21.5 \\
\hline Sedang & $78-91$ & 63 & 67.7 \\
\hline Rendah & $<78$ & 10 & 10.8 \\
\hline \multicolumn{2}{|c|}{ Jumlah } & 93 & 100 \\
\hline
\end{tabular}


Hubungan Antara Penilaian Anak Terhadap Cerita Film...; Ratna Sesotya Wedadjati

Tabel 3 Kategori subjek pada skala empati

\begin{tabular}{|l|c|c|c|}
\hline \multicolumn{1}{|c|}{ Kategori } & Rentang skor & Jumlah & Frekuensi (\%) \\
\hline Tinggi & $102-116$ & 8 & 8,6 \\
\hline Sedang & $87-101$ & 82 & 88,2 \\
\hline Rendah & $<87$ & 3 & 3,2 \\
\hline \multicolumn{2}{|c|}{ Jumlah } & $\mathbf{9 3}$ & $\mathbf{1 0 0}$ \\
\hline
\end{tabular}

gorof-Smirnov program SPSS (Statistic Program for Social Science), uji ini dilakukan untuk mengetahui apakah data setiap variabel penelitian mempunyai distribusi normal atau tidak. Kaidah yang digunakan adalah jika nilai signifikansi $<0.05$ sebaran dianggap tidak normal dan jika nilai signifikansi e" 0.05 maka sebaran dianggap normal. Analisis dilakukan dari hasil tabulasi data skala penilaian anak dan skala kemampuan empati. Hasil uji normalitas terhadap ke-dua variabel sebagai berikut :

a. Variabel penilaian anak menunjukkan koefisien $\mathrm{K}-\mathrm{SZ}=0.714$, signifikansi $=$ 0.605

b. Variabel kemampuan empati menunjukkan koefisien K-SZ $=0.661$, signifikansi $=0.775$
Untuk lebih jelas rangkuman hasil uji normalitas sebaran dapat dilihat pada tabel 4.

Berdasarkan tabel diatas dapat disimpulkan bahwa, variabel penilaian anak nilai signifikansi e" 0.05 maka sebaran dianggap normal dan variabel kemampuan empati signifikansi e" 0.05 maka dinyatakan distribusinya normal, maka dapat disimpulkan bahwa semua variabel berdistribusi normal.

\section{2.. Uji linieritas.}

Uji linieritas dilakukan untuk mengetahui linieritas variabel kemampuan empati dengan penilaian anak memiliki hubungan yang linier. Selain itu uji linieritas dapat pula diketahui taraf penyimpangan dari linieritas

Tabel 4. Hasil Uji Normalitas Sebaran

\begin{tabular}{|l|c|c|c|c|c|}
\hline \multicolumn{1}{|c|}{ Variabel } & Mean & Std.Dev & K-SZ & Asymp. Sig. (2-tailed) & Keterangan \\
\hline Penilaian anak & 87.0606 & 8.6600 & 0.661 & 0.775 & Normal \\
\hline Kemampuan empati & 86.8857 & 7.10285 & 0.714 & 0.605 & Normal \\
\hline
\end{tabular}

Keterangan :

Std. Dev: Standar Deviasi

K-SZ

: Koefisien Uji Normalitas

Sig.

: Signifikansi 
UNISIA, Vol. XXXII No. 72 Desember 2009

hubungan tersebut. Variabel independen dan dependen dianggap linier apabila tidak ditemukan penyimpangan yang berarti.

Uji linieritas pada penelitian ini dilakukan dengan menggunakan teknik analisis variabel. Kaidah yang digunakan adalah jika nilai signifikansi $<0.05$ maka hubungan kedua variabel linier dan jika nilai signifikansi e" 0.05 maka hubungan kedua variabel dianggap tidak linier. Berdasarkan hasil uji asumsi nila $f=21.90$ dan signifikansi 0.000 , maka dapat disimpulkan bahwa variabel penilaian anak dihubungkan dengan variabel kemampuan empati nilai signifikansi $<0.05$ maka hubungan kedua variabel linier.

\section{Hasil Analisis Data Uji Hipotesis}

Setelah proses uji asumsi dilakukan sebagai prasarat dalam pengujian hipotesis, maka selanjutnya melakukan uji hipotesis. Analisis yang digunakan untuk menguji hipotesis ini adalah analisis product moment. Hasil analisis diporelah nilai koefisien korelasi $=0.382$, bermakna bahwa antara kemampuan empati berkorelasi dengan penilaian anak. Nilai signifikan (1-tailed) $=$ 0.000 dengan taraf kesalahan yang ditentukan pada level $0.01 \%$ (taraf kepercayaan $99 \%$ ) sehingga Ho ditolak dan Ha diterima. Jadi dapat disimpulkan, bahwa ada hubungan positif yang sangat signifikan antara penilaian anak terhadap cerita film anak di televisi dengan kemampuan empati, semakin positif anak menilai tayangan film tersebut maka semakin tinggi kemampuan empatinya. Hipotesis ini diterima karena secara statistik terbukti memiliki signifikansi yang kuat. Hasil analisis diperoleh nilai RSquare 0.171 dengan demikian dapat katakan bahwa kemampuan empati memberikan sumbangan efektif sebesar $17.1 \%$ terhadap penilaian anak terhadap cerita film anak di televisi.

\section{Pembahasan}

Dari hasil analisis data dengan teknik korelasi product moment menunjukkan bahwa antara kemampuan empati dan penilaian anak terhadap cerita film anak di televisi memiliki hubungan positif yang signifikan pada level 0.01 (1-tailed) dengan $r$ sebesar 0,382. Hal ini berarti bahwa semakin positif anak menilai tayangan film tersebut maka semakin tinggi kemampuan empatinya.

Hasil penelitian ini mendukung pendapat Brown (dalam Habib,2001) yang menyatakan bahwa teelvisi sebagai media massa, memiliki tiga fungsi utama yaitu sebagai media informasi (infirmation), sebagai media pendidikan (education), dan sebagai media hiburan (entertainment), sehingga sesuai dengan fungsinya televisi sangat memungkinkan untuk dimanfaatkan sebagai media pendidikan, karena dalam berbagai hal televisi dapat memberikan, rangsang, membawa serta, memicu, membangkitkan serta mempengaruhi seseorang untuk melakukan sesuatu, memberikan saran-saran, memberikan warna, mengajar, menghibur, memperkuat, menggiatkan, menyampaikan pengaruh dari orang lain, memperkenalkan berbagai identitas atau ciri sesuatu, memberikan contoh perilaku, proses internalisasi tingkah laku, berbagai bentuk partisipasi serta penyesuaian diri dan sebagainya.

Sebagai makhluk sosial, perilaku manusia secara umum banyak dipengaruhi berbagai faktor, baik dari dalam diri sendiri (organismic forces) maupundari luar diri sendiri (environmental force). Manusia berberpikir, merasa, bersikap dan bertindak karena adanya rangsangan dari luar dirinya.

Televisi adalah jendela dunia rumah tangga yang tidak aman sekali bagi anggota kelompok sosial tersebut yang disebut 
Hubungan Antara Penilaian Anak Terhadap Cerita Film...; Ratna Sesotya Wedadjati

keluarga karena anggota keluarga menjadi "bertambah" dengan hadirnya tokoh-tokoh lain dari luar ruamah, luar kota, luar negeri dan bahkan luar angkasa. Pesan-pesan dan informasi melalui televisi baik yang bersifat hiburan maupun penerangan dan pendidikan makin deras membanjiri anak-anak dan masyarakat pada umumnya, serta model perilaku dan tokoh identifikasi diri semakin anyak ditawarkan.

Selain itu media televisi juga merupakan wahana yang kuat sekali pengaruhnya dalam pembentukan pola pikir, sikap dan tingkah laku di samping menambah pengetahuan dan memperluas wawasan, hal itu dikarenakan oleh adanya daya penetrasi televisi yang sangat kuat terhadap kehidupan manusia sehingga mampu merubah sikap, pendapat dan perilaku seseorang dalam rentang yang relatif singkat.

Media televisi dapat membantu mengembangkan kemampuan empati pada anak melalui program-program acara yang disajikan dalam hal ini adalah melalui pemutaran film cerita anak-anak ditelevisi, karena suatu program televisi mampu menyajikan pesan-pesan yang jelas kepada pemirsanya tentang hal-hal yang pantas atau patut ditiru, dengan kata lain program-program yang disajikan hendaknya tidak bertentangan dengan norma-norma kesusilaan, adat istiadat dan sopan santun ketimuran yang hidup dalam masyarakat Indonesia khususnya anak-anak. Pendapat ini didukung oleh Widarto (1994) yang menyatakan, bahwa program yang disajikan televisi hendaknya mampu membentuk seseorang untuk mampu berpikir kritis, mempunyai kedisiplinan dan ketaatan terhadap nilai-nilai dan norma dalam masyarakat agar mampu mengambil keputusan dan perilaku yang terbaik, sehingga pemirsanya mampu memilih halhal yang patut ditiru maupun hal-hal yang tidak patut ditiru.

Menurut Sedyawati (dalam Habib, 2001) sifat-sifat yang baik yang perlu ditanamkan pada anak ada 56 butir sifat baik yaitu bekerja keras, berani memikul resiko, berdisiplin, beriman, berhati lembut, berinisiatif, berpikir matang, berpikir jauh kedepan, bersahaja, bersemangat, bersifat kontruktif, bersyukur, bertanggung jawab, bertenggang rasa, bijaksana, cerdik, cermat, dinamis efisien, gigih, hemat, jujur, berkemauan keras, kreatif, kukuh hati, lugas, mandiri, mawas diri, menghargai waktu, pemaaf, pemurah, pengabdian, pengendalian diri, produktif, rajin, ramah tamah, rasa kasih sayang, rasa percaya diri, rela berkorban, rendah hati, sabar, sportif, susila, tangguh, tegas, tekun, tepat janji, terbuka dan ulet.

Sifat-sifat baik diatas dapat dipelajari anak dan ditiru dengan cara menonton film cerita anak di televisi, karena televisi mempunyai kekuatan dari dua arah yaitu kekuatan pandang dan dengar. Siaran televisi memiliki potensi penetratif untuk mempengaruh sikap, pandangan, gaya hidup, orientasi dan motivasi masyarakat.

Televisi adalah media yang potensial sekali untuk menyampaikan informasi dan membentuk perilaku seseorang, baik kearah yang positif maupun negatif yang dilakukan secara sengaja maupun tidak sengaja. Proses perubahan perilaku bukanlah proses yang sekali jadi tetapi memerlukan waktu yang relatif sifatnya, perilaku bukan pula bawaan atau turunan tetapi lebih merupakan produk belajar, yang mencakup kawasankawasan kognitif, afektif dan psikomotor.

Frekuensi dan intensitas informasi yang diperoleh individu akan menentukan apakah perilaku seseorang akan terpengaruh oleh informasi tersebut. Informasi yang sama, senada atau serupa yang masuk secara 
UNISIA, Vol. XXXII No. 72 Desember 2009

berulang-ulang didalam diri seseorang akan memberikan pengaruh berbeda dengan apabila informasi tersebut hanya diterima sekali. Seringkali tanpa disadari informasi tersebut terinternalisasi kedalam diri dan selanjutnya terealisasi dalam bentuk perilaku tertentu, bahkan sesuatu informasi yang salah karena berulang-ulang disampaikan tanpa disadari akan dianggap sebagai suatu kebenaran. Pola tingkah laku diperoleh melalui pengalaman langsung maupun melalui pengamatan terhadap tingkah laku orang lain, kegiatan, tindakan dan tingkah laku sedikit banyak ditentukan oleh konsekuensi-konsekuensi yang dibayangkan akan datang baik positif maupun negatif. Apa dan bagaimana akibat yang ditimbulkan oleh suatu perbuatan akan menentukan apakah perbuatan tersebut akan terulang oleh yang bersangkutan atau tidak.

Perilaku atau tindakan yang mendatangkan efek yang positif akan menyenangkan dan cenderung untuk dilakukan kembali di masa mendatang. Sebaliknya, perilaku atau tindakan yang memberikan efek negatif dan tidak enak cenderung untuk tidak diulang lagi. Kemam-puan empati dapat ditiru anak dari tokoh-tokoh yang ada disekitarnya, misal dari orang tua, kakek, neneknya serta dari teman setia mereka yaitu tokoh-tokoh film yang mereka sukai.

Televisi merupakan sebagaian dari sekian banyak faktor yang berasal dari luar diri individu yang berpengaruh pada perubahan perilaku akan tetapi dampak dari televisi sangat mudah dilihat. Kemampuan empati anak dapat juga diperoleh dari penilaian anak terhadap tokoh-tokoh cerita film anak yang digemari di televisi, kemudian anak-anak mengelaborasi segi positif dan negatif untuk kemudian membedakan mana yang boleh ditiru dan mana yang tidak boleh ditiru. Untuk dapat membantu membedakan ini tentunya anak memerlukan pendamping yang setia ketika mereka menyaksikan tayangan program acara film anak-anak ditelevisi yaitu orang tua yang membimbing. Besarnya sumbangan efektif penilaian anak terhadap kemampuan empati sebesar $17.1 \%$, berarti ada faktor lain yang cukup berperan dalam memprediksi kemampuan empati.

Berkaitan dengan perkembangan kemampuan empati banyak sekali kemungkinan yang mampu mengembangkan potensi ini yaitu adalah melakukan kegiatan belajar. Menurut Hurlock (1991) anak-anak akan belajar dari berbagai pihak antara lain : belajar bebas dari orang dewasa, belajar kepada kelompok, belajar menyesuaikan diri dengan standar kelompok, belajar bermain dan olah raga, belajar turut berbagi rasa dengan orang yang dianiaya, belajar bersikap sportif, belajar menerima dan belajar melaksanakan tanggung jawab, serta belajar bersaing dengan orang lain. Anak akan mampu memilih mana yang baik untuk ditirukan dan mana yang tidak baik untuk ditiru dengan adanya proses belajar yang bermacam sehingga dari proses belajar ini akan tumbuh kemampuan empati.

\section{Penutup}

\section{Kesimpulan}

Berdasarkan analisis data dan pembahasan maka dapat ditarik kesimpulan sebagai berikut : ada hubungan positif yang sangat signifikan antara penilaian anak terhadap cerita film anak di televisi dengan kemampuan empati, semakin positif anak menilai tayangan film tersebut maka semakin tinggi kemampuan empatinya. Kemampuan empati yang dimiliki oleh subjek rata-rata sedang. 
Hubungan Antara Penilaian Anak Terhadap Cerita Film...; Ratna Sesotya Wedadjati

\section{Saran}

Bagi orang tua, disarankan untuk membimbing dan mendampingi anakanaknya dalam menonton televisi, memilih acara-acara yang tepat dan cocok untuk usia anak, memberikan pengertian dan pemahaman terhadap perilaku tokoh-tokoh yang ada serta isi dari cerita film atau program acara ditelevisi, karena dengan cara itulah orangtua dapat meminimalkan dampak negatif dari tayangan televisi.

Bagi para guru, disarankan untuk selalu membekali pendidikan moral bagi siswa siswinya mengingat kondisi saat sekarang yang merupakan era global dalam dunia komunikasi, segala macam informasi dan hiburan dengan mudah diperoleh melalui televisi, internet, email, serta berbagai macam peredaran VCD dan DVD yang banyak mengandung unsur agresivitas dan pornografi, sehingga diharapkan guru mampu menciptakan situasi yang inovatif dan memahami perkembangan anak agar mampu menghasilkan anak didik yang berkualitas dan bermoral.

\section{Daftar Pustaka}

Azwar, S. 1998. Sikap Manusia; Teori dan Pengukurannya. Edisi 2. Yogyakarta: Pustaka Pelajar. 1999. Penyusunan Skala Psikologi. Yogyakarta:Pustaka Pelajar.

Crick, N.R., Casas, J.F.,Mosher, M. 1997. Relational and Overt Aggression in Preschool. Journal of Development Psychology, Vol. 33. No. 4. 579-588.

Davis, M. H. 1983. Measuring Individual Differences in Empathy : Evidence for a Multidimensional Aprroach. Journal of
Personality and Social Psychology. Vol. 44. No. 1. 113-126.

Dayakisni, T. 1996. Pengaruh Pelatihan Kepekaan Sosial terhadap Peningkatan Perilaku Prososial. Tesis (Tidak diterbitkan). Yogya-karta.: Fakultas Psikologi Universitas Gadjah Mada.

Dhamayanti, R.W. 2000. Kecanduan Nonton Teletubies, Bolehkah?. http://www. Lippostar.com

Hafni, M. 2002. Pengaruh Tayangan Film Cerita Anak-Anak terhadap Intensi Perilaku Altruitik pada Anak Usia Sekolah. Tesis (Tidak diterbitkan). Yogyakarta.:Fakultas Psikologi Universitas Gadjah Mada.

Habib, Z., Waldopo, dan Indrayanti, Ch. 2001. Penelitian Film Anak-Anak di TV dalam Rangka Pengembangan Program Pendidikn Budi Pekerti. Jurnal Teknodik. Edisi No 9/V/ Teknodik/Oktober 2001/www. pustekom.go.id.

Hurlock, E.B. 1991. Psikologi Perkembangan anak. Terjemahan Jakarta: Erlangga.

Intisari. 1999. Mari Diet TV Keluarga. Kumpulan Artikel Intisari Psikolog Anak.

Jatman, D. 2003. Perubahan Sosial Budaya Selalu Berdampak Pada Masyarakat Dalam Menyikapi Anak Bermasalah. Makalah disampaikan dalam Temu IImiah Nasional III (Ikatan Psikologi Perkembangan Indonesia- IPPI). 6-8 Maret 2003. Yogyakarta. 
UNISIA, Vol. XXXII No. 72 Desember 2009

Ladd, W.G., Lange, G. And Stremmel, A. 1983. Personal and Situasional Influences on Children' Helping Behavior : Factor That Mediate Compliant Helping. The Society for Research in Child Development, Inc.

Lewis, P. 1993. Cara Mengarah Anak: Anak Anda Dapat Menjinakkan si Monster Televisi. Bandung:Yayasan Kalam Hidup.

Lorch, E.P., Bellack, D. R., Augsbach, H.L. 1987. Young Children's Memory for Televised Stories : Effects of Importance. The Society for Research in Child Development, Inc.

Puspito, H. 2002. Anak-Anak dan Televisi. http://www.Suaramerdeka.com
Selular, Oktober 2003. No. 43. Mobile Learning.

Tuhehay, K. 2003. "Demi Bangsa, Selamatkan Anak". Gerbang Majalah Pendidikan. Edisi 11 Tahun II, Mei 2003

Vandell, D. L. 2000. Parents, Pear Groups, and Other Socializing Influences. Developmental Psychology. Vol. 36. No. 6. 699-710.

Widarto, S. 1994. Pendayagunaan Siaran Televisi untuk Pendidikan Sumber Daya Manusia. Seminar Lokakarya Nasional Teknologi Pendidikan tentang : Media Massa Elektronik dan Pendidikan Sumber Daya Manusia. http://www.pustekom.go.id. 